DOI: 10.34015/2523-4552.2021.2.05

УДК 343.31+343.852

Беленок В. П., здобувач наукової лабораторії з проблем протидії злочинності ННІ № 1 Національної академії внутрішніх справ ORCID: 0000-0001-8214-0522

\title{
КРИМІНОЛОГІЧНА ХАРАКТЕРИСТИКА ОСІБ, ЯКІ ВЧИНИЛИ ПОГРОЗУ АБО НАСИЛЬСТВО ЩОДО ПРАЦІВНИКА ПРАВООХОРОННОГО ОРГАНУ
}

У статті на підставі аналізу судової практики, статистичних даних, результатів досліджень учених розкрито особливості кримінальних правопорушників цієї категорії за ознаками громадянства, національності, віку, статі, освітнього рівня, судимості, співучасті, фізичного стану, працевлаштування та місця проживання. Розроблено кримінологічний портрет особи, яка вчиняє погрози або насильство щодо працівників правоохоронних органів у зв'язку з виконанням цим працівником службових обов'язків: чоловік у віці 2550 років, громадянин України, місцевий мешканець міста, з загальною середньою або професійно-технічною освітою, котрий офіційно не працевлаштований, зловживає алкогольними напоями та раніше вчинив адміністративне чи кримінальне правопорушення (у певних випадках раніше судимий).

Ключові слова: погроза; насильство; працівник правоохоронного органу; близькі родичі; особа злочинця; суб'єкт злочину.

В статье на основании анализа судебной практики, статистических данных, результатов исследований ученых раскрыты особенности уголовных правонарушителей этой категории по признакам гражданства, национальности, возраста, пола, образовательного уровня, судимости, соучастия, физического состояния, трудоустройства и места жительства. Разработан криминологический портрет лица, совершающего угрозы или насилие в отношении сотрудника правоохранительного органа в связи с исполнением этим работником служебных обязанностей: мужчина в возрасте 25-50 лет, гражданин Украины, местный житель города, с общим средним или профессионально-техническим образованием, который официально не трудоустроен, злоупотребляет алкогольными напитками и ранее совершил административное или уголовное правонарушение (в определенных случаях ранее судимый).

Ключевые слова: угроза; насилие; работник правоохранительного органа; близкие родственники; личность преступника; субъект преступления.

Постановка проблеми. Серед пріоритетних завдань розбудови України як правової держави євро- пейського зразка $є$ створення ефективної правоохоронної системи, важливою складовою якої $\epsilon$ забезпе- 
чення високого рівня захисту правоохоронців. Саме ефективність діяльності вітчизняних правоохоронних органів у певній мірі залежить від рівня захисту прав і свобод їх працівників, який з огляду на виконувані ними функції, повинен мати високий ступінь. Насамперед слід створити належні умови захисту життя та здоров'я правоохоронців, котрі щоденно перебувають в умовах небезпеки посягань з боку осіб, що вчиняють адміністративні чи кримінальні правопорушення. Особливої небезпеки зазначені посягання набувають в умовах зростання рівня корупції, організованої злочинності та тероризму, на чому неодноразово наголошували вчені $[1$, с. $5-8 ; 2$, с. 1 ; 3 , с. $21 ; 4$, с. $44-47 ; 5$, с. $6-9 ; 6$, с. 6].

Забезпечення ефективної системи кримінально-правової охорони працівників правоохоронних органів від погроз та насильства, а також запобігання цим кримінально протиправним діянням неможлива без вивчення особи злочинця.

Аналіз останніх досліджень і публікацій. Окремі кримінальноправові, кримінологічні та криміналістичні особливості осіб, які вчинили погрози або насильство щодо працівників правоохоронних органів, досліджено у працях А. В. Бойка, Л. П. Брич, О. О. Кирбятєва, В. А. Клименка, В. І. Осадчого, М. В. Сийплокі, А. М. Удода, I. Д. Метельського та інших науковців. Разом із тим чимало питань кримінологічної характеристики осіб, які вчинили погрозу або насильство щодо працівника правоохоронного органу залишаються недостатньо дослідженими.

Постановка завдання. Мета статті - на підставі наявної емпірич- ної бази, а також досліджень вчених узагальнити кримінологічні ознаки осіб, які вчинили погрозу або насильство щодо працівника правоохоронного органу.

Виклад основного матеріалу. Особу злочинця вивчають за ознаками віку, статі, сімейного стану, судимості, працевлаштування, освітнього рівня, громадянства, національності тощо. Ознаки особи злочинця у кримінальному праві використовуються для індивідуалізації кримінального покарання та вирішення питань, пов'язаних із звільненням від кримінальної відповідальності та покарання. У криміналістиці ці ознаки вивчаються для розробки методики розслідування кримінального правопорушення, а в кримінології - для розробки заходів запобігання суспільно небезпечним діянням [7, с. 81]. Зазначені ознаки прийнято називати соціально-демографіч-ними. Незважаючи на те, що вони становлять основу кримінологічної характеристики особи злочинця, не слід оминати й інші групи ознак цього суб'єкта, зокрема кримінально-правові, соціально-психологічні, соціально-рольові на які слушно звертають увагу кримінологи $[8$, с. $107 ; 9$, с. $87 ; 10$, с. 135$]$. Комплексний аналіз зазначених ознак надасть можливість сформувати повну та об'єктивну характеристику осіб, які вчиняють насильство або погрози щодо працівника правоохоронного органу.

Громадянство та національність. Аналіз доступної емпіричної бази засвідчує, що з 288 осіб, засуджених у 2020 р. за ст. 345 КК України, 98 \% складали громадяни України та 1,7\% громадяни іншої держави. Дослідження судової практики показало відсутність будь-яких інших особ- 
ливостей, пов'язаних з національною чи етнічною приналежністю кримінальних правопорушників. Перевага українців обумовлена насамперед тим, що вони логічно займають найбільшу частку в структурі громадян, які проживають на території України. Водночас серед громадян України, які вчиняють ці злочини не лише українці, але й представники інших національностей. Не випадково опитані працівники ДВБ НП України серед злочинців цієї категорії називають ще й представників етнічних національних меншин.

місце прожсивання. Вивчення судової практики свідчить про те, що такі злочини здебільшого вчиняють мешканці міст. Зазвичай вони вчиняються у тому місці, де проживає кримінальний правопорушник.

Cmamь. Відомості про стать засуджених свідчить про те, що такі злочини вчиняють переважно чоловіки. 3288 осіб, засуджених у 2020 р. за ст. 345 КК України, за ознакою статі 88,9 \% складали чоловіки та 11,1 \% - жінки.

Значна перевага чоловіків обумовлена тим фактом, що вони значно частіше вчиняють адміністративні та кримінальні правопорушення, які передують погрозам або насильству щодо працівників правоохоронних органів (це порушники правил дорожнього руху, особи, які вчиняють домашнє насильство, розпивають алкогольні напої у заборонених законом місцях, з'являються в громадських місцях у п'яному вигляді, хулігани тощо). Окрім того, злочин, передбачений ст. 345 КК України, у більшості випадків вчиняється шля- хом застосування фізичної сили переважно відносно чоловіків, які мають спеціальну фізичну підготовку. Зважаючи на це переважна частина фізичного насильства вчиняється чоловіками, які здебільшого фізично сильніші за жінок.

Перевага осіб чоловічої статті певною мірою обумовлена й різною реакцією чоловіків та жінок на певні подразники (наприклад, правомірні або неправомірні дії правоохоронців).

Зазвичай порушниці цієї категорії $є$ повнолітніми, хоча в судовій практиці трапляються випадки вчинення погрози або насильства щодо працівників поліції особами, які не досягли 18 річного віку [11].

Типовими ситуаціями вчинення злочину, передбаченого ст. 345 КК України, жінками є наслідування своїх чоловіків, які здійснюють погрози або насильство щодо правоохоронців (наприклад, Особа_3 після того як їі чоловік завдав легких тілесних ушкоджень одному поліцейському, завдала легких тілесних ушкоджень іншому поліцейському) [12] та обурення тим, що їх чоловіків намагаються притягнути до відповідальності (наприклад, Особа_2 будучи обуреною діями поліцейських, які складали відносно її чоловіка матеріали про адміністративне правопорушення, накинулась на інспектора патрульної поліції та почала наносити йому удари по обличчю) [13].

Вік. Щодо вікових особливостей варто відмітити, що на момент вчинення злочину $0,7 \%$ засудженим у 2020 р. було 16-18 років ${ }^{*}, 17 \%$ - 1825 років, $19 \%$ - 25-30 років, 54,5\% -

* У 2020 р. з 620 кримінальних правопорушень, за якими провадження направлені до суду, 1,1 \% - кримінальні правопорушення вчинені неповнолітніми або за їх участю. 
30-50 років, $8 \%$ - 50-65 років, і 0,7\% - 65 років і старше. Таким чином найбільшу криміногенну групу за віковою ознакою становлять особи у віці $30-50$ років $(54,5 \%)$. Особи у віці 18-25 років та 25-30 років такі злочини вчиняють значно рідше (відповідно $17 \%$ та $19 \%$ ). Натомість неповнолітні та особи 65 років i старше їх майже не вчиняють. Водночас важко не помітити певну залежність вікових характеристик правопорушників цієї категорії i кількості відповідних кримінально протиправних діянь. В осіб віком від 16 до 50 років зі збільшенням віку зростає рівень криміногенності суб'єкта. В межах вікового діапазону 16-50 років чим старша особа, тим більша ймовірність вчинення нею погроз або насильства щодо правоохоронців.

освіта. Кримінологи слушно відзначають, що характеристика освітнього рівня кримінального правопорушника має важливе значення, адже відповідний рівень тісно пов'язаний із загальною культурою особистості, iї інтелектуальним розвитком та соціальним статусом, правосвідомістю і правовою культурою, колом контактів, життєвими планами та можливостями їх реалізації [14, c. 75].

Серед засуджених у 2020 p. $44,1 \%$ особи мали повну загальну середню, 26\% - професійно-технічну, $15,3 \%$ - базову загальну середню, $8,7 \%$ - повну вищу освіту, 4,9\% базову вищу, 0,7\% - початкову загальну та $0,3 \%$ засуджених було без освіти. Відтак можна стверджувати, що найбільш криміногенні групи за освітнім рівнем утворюють особи із загальною середньою (зазвичай повною, рідше базовою) та професійно- технічною освітою (разом - 85,4 \%). Натомість особи без освіти та особи із початковою загальною освітою злочини, передбачені ст. 345 КК України, практично не вчиняють (0,3 \% та 0,7 \% відповідно), а особи 3 вищою освітою вчиняють рідко $(13,6 \%)$.

Незначний відсоток осіб без освіти та осіб із початковою загальною освітою обумовлений тим, що сучасна система освіти в України дає можливість усім одержати базову середню освіту, а держава усіляко забезпечує це право. Відповідно до ч. 2 ст. 53 Конституції України повна загальна середня освіта $\epsilon$ обов'язковою. А батьки або особи, які їх замінюють, зобов'язані забезпечити умови для здобуття дитиною повної загальної середньої освіти.

Мають рацію вчені в тому, що «чим вищий рівень освіти особи тим менша ймовірність вчинення нею злочину $[15$, с. 106$]$. Ймовірно це можна пояснити тим фактом, що особи 3 вищою освітою значно менше потрапляють в поле зору правоохоронців. Окрім того, у разі виникнення конфлікту з правоохоронцями вони воліють вирішити його мирним шляхом, зокрема в правовому полі, або шляхом підкупу правоохоронців. Особи з вищою освітою краще усвідомлюють правові наслідки вчинення своїх протиправних дій. Серед них значно менше схильних до вчинення насильницьких злочинів.

Невисока питома вага серед розглянутих злочинців освічених і високо освічених громадян може бути пояснена впливом цілого комплексу негативних тенденцій в детермінації злочинності: диспропорція громадян за рівнем доходів і достатку, що продовжує збільшуватися; збільшення 
прошарку людей, які перебувають за межею бідності; зростання алкоголізації населення; зниження його культурного рівня; морально-ціннісна дезорієнтація тощо. Тому цілком закономірним $є$ те, що серед осіб, які посягають на представників влади, переважають особи, котрі мають середню освіту [15, с. 107].

Невисокий освітній рівень злочинців даної категорії може бути пояснений і тією обставиною, що сам характер посягання на представника влади такий, що не вимагає певного рівня розвитку, а механізм злочину досить простий у виконанні і не вимагає серйозного морального осмислення своїх вчинків [15, с. 107-108].

Водночас вчинення цих злочинів особою з вищою освітою можливо можна пояснити тим, що, як слушно зауважує А. В. Андрушко «наявність вищої освіти у деяких засуджених $є$ формальністю, тобто свідчить тільки про наявність відповідного диплома, а не підтверджує фактичний високий рівень у них культури, світогляду, моральних принципів та ціннісних орієнтацій. Окреслений стан речей, вочевидь, можна пояснити зниженням якості освіти, що відбувається в Україні протягом останніх десятиліть [16, с. 123].

Судимість. Одним з факторів, що вказує на соціальну орієнтацію особистості, $€$ наявність судимості, як показник наявності злочинного досвіду і кримінальної спрямованості особистості. Дійсно про стійкість антисоціальної спрямованості кримінальних правопорушників цієї категорії свідчить факт попереднього засудження цих суб'єктів. Водночас сукупність антисуспільних установок, недостатньо стійкої життєвої позиції, злочинних цілей і мотивів знаходить своє вираження в характері злочинної поведінки, способах і наслідках вчинених злочинів. Відомості про колишню кримінальну спрямованість винних можуть слугувати основою для прогнозування індивідуальної злочинної поведінки і профілактичного впливу на осіб, схильних до прояву насильства [15, c. 119-120].

У 2020 р. 3620 кримінальних правопорушень, за якими провадження направлені до суду, 19,8 \% складали кримінальні правопорушення вчинені особами, які раніше вчиняли кримінальні правопорушення. Натомість серед засуджених у 2020 р. за ст. 345 КК України ситуація дещо інша: 0,3 \% становлять особи, які раніше вчинили злочини, але були звільнені від кримінальної відповідальності, 4,9\% - особи, які судилися, але визнані такими, що не мають судимості, 8,3 \% - особи, які судилися, але судимість погашена чи знята. $14 \%$ засуджених на час вчинення злочину мали не зняту і непогашену судимість. Це майже половина $(49,4 \%)$ від усіх осіб, яким призначено покарання у 2020 р.

Таким чином, серед засуджених особи, які раніше вчиняли злочини, i по яких є судові рішення, складають 27,5 \%. Водночас слід взяти до уваги той факт, що погрозам або насильству щодо правоохоронців як правило передує факт вчинення суб'єктом злочину, передбаченого ст. 345 КК України, іншого адміністративного або кримінального правопорушення, а також певну частку латентності кримінально-протиправних діянь в цілому. Відтак більше третини, а можливо й більше половини осіб, які вчинили погрозу або насильство щодо працівників правоохоронних ор- 
ганів, мали досвід кримінально протиправної діяльності.

Серед засуджених, які мали не зняту і непогашену судимість на час вчинення злочину 47,5 \% (6,6\% від усіх засуджених) осіб мали одну судимість, 17,5 \% (2,4 \% від усіх засуджених) осіб - дві судимості, $35 \%$ (4,9\% від усіх засуджених) осіб - три і більше судимості.

Серед засуджених, які мали не зняту і непогашену судимість на час вчинення злочину, найбільше $62,5 \% \quad(8,7 \%$ від усіх засуджених $)$ мало судимість за злочини проти власності, 22,5 \% (3,1\% від усіх засуджених) - за злочини проти життя чи здоров'я особи, 7,5 \% (1,04\% від усіх засуджених) - за злочини, пов'язані з наркотиками, 2,5 \% (0,3% від усіх засуджених) - за злочини проти безпеки руху та експлуатації транспорту, 2,5 \% (0,3% від усіх засуджених) - за злочини проти громадського порядку, моральності, 2,5 \% (0,3 \% від усіх засуджених) - за інші злочини.

Серед засуджених, які мали не зняту і непогашену судимість на час вчинення злочину, $40 \%(5,6 \%$ від усіх засуджених) осіб відбули покарання повністю, $20 \%$ (2,8\% від усіх засуджених) осіб звільнені від покарання (умовно-достроково, у зв'язку з амністією та 3 інших підстав), 7,5 \% (1,04\% від усіх засуджених) скоїли злочин, не відбувши покарання, $25 \%$ (3,5 \% від усіх засуджених) осіб учинили злочин у період відбуття покарання в місцях позбавлення чи обмеження волі або арешту, 7,5 \% (1,04 \% від усіх засуджених) осіб учинили злочин у період іспитового строку.

Перебуваючи у місцях позбавлення волі в таких осіб досить часто формуються нові навички вчинення кримінально-протиправних діянь, стійка антисуспільна установка. Нерідко вони встановлюють зв'язки з представниками організованої злочинної спільноти.

Водночас результати досліджень свідчать про те, що значна часина погроз або насильства щодо працівників правоохоронних органів вчиняється особами, що не мають кримінального минулого. Варто погодитися 3 тим, що «даний факт можна розцінити як прояв агресивності суспільства, падіння авторитету влади в цілому і ії окремих представників, готовності громадян вирішувати конфліктні ситуації за допомогою насильства» $[15$, с. 120$]$.

Співучасть. У співучасті погроза або насильство щодо працівників правоохоронних органів вчиняється рідко. У 2020 р. 3620 кримінальних правопорушень, за якими провадження направлені до суду, лише 2,4 \% становили діяння вчинені групою осіб. Натомість серед засуджених у 2020 р. злочин у складі групи вчинили 7,3\% осіб. Водночас у певних випадках групові посягання на правоохоронців $\epsilon$ більш небезпечними, порівняно 3 посяганнями індивідуальних суб'єктів. Це стосується посягань в яких беруть участь десятки, а то й сотні осіб (наприклад, рейдерські захоплення або групові насильницькі дії під час масових акцій протесту). Підвищена небезпека таких посягань в тому, що потерпілими як правило $є$ не один, а декілька правоохоронців. Більш небезпечними $є$ й посягання на правоохоронців, вчинені кримінальними авторитетами, організаторами та активними учасниками організованих злочинних об'єднань. Ці суб'єкти після фізичного насильства можуть 
перейти до посягання на життя працівників правоохоронних органів.

Стан сп'яніння. Одним 3 найбільш впливових «стимуляторів» погроз або насильства щодо працівників правоохоронних органів є стан сп'яніння. У 2020 р. 3620 кримінальних правопорушень, за якими провадження направлені до суду, 38,1 \% - кримінальні правопорушення вчинені особами у стані алкогольного сп'яніння. Натомість серед засуджених у 2020 р. цей показник ще більший - 49,3\%.

У стані сп'яніння людина втрачає звичну реакцію на зовнішні подразники; у неї посилюється збудливість i, навпаки, послаблюються, або зовсім паралізуються, соціально вироблені гальмівні процеси. Людина стає розв'язаною, нестримною, запальною, грубою, втрачає здатність до самоконтролю. У неї вивільняються i дають про себе знати аморальні і антисуспільні спонукання, які в нормальному стані придушуються. Зрозуміло, поведінка людини, що знаходиться в стані сп'яніння, обумовлена не безпосереднім впливом алкоголю, а рядом інших факторів, пов'язаних 3 вихованням, звичною поведінкою, психологією та моральним обличчям особи. Найчастіше алкогольне сп'яніння не вносить нічого нового в мотиви дій злочинця, а виявляє і реалізує бажання, нахили, наміри, що сформувалися у нього раніше [15, с. 117].

Як свідчить практика у певних випадках кримінальні правопорушники, перебуваючи в стані алкогольного сп'яніння не повною мірою усвідомлюють свої дії, а тому потім не можуть пояснити чому вчинили посягання на правоохоронців $[17 ; 18]$.
Працевлаштування. Серед осіб, засуджених у 2020 р. за вчинення злочину, передбаченого ст. 345 КК України, більшість становили працездатні, які не працювали і не навчалися - 72,2 \% (9\% з них мають не зняту i непогашену судимість), робітники складали $12,2 \%$, особи, які утримувалися в установі виконання покарань, під вартою - 4,2\%, пенсіонери, у т.ч. інваліди - 3,5\%, приватні підприємці - 1,7\%, інші службовці 0,7 \%, працівники господарських товариств - 0,7\%, студенти навчальних закладів - 0,7 \%, військовослужбовці - 0,3 \%, учні шкіл, ліцеїв, коледжів, гімназій - 0,3 \%, безробітні $-0,3 \%$, інші заняття - 3,2\%.

Таким чином, більшість правопорушників цієї категорії (72,2%) становлять працездатні особи, які офіційно не працевлаштовані. Такий великий відсоток офіційно не працевлаштованих у певній мірі можна пояснити такими обставинами: 1) нині в України високий рівень безробіття; 2) офіційне працевлаштування досить часто невигідне працівнику та/або працедавцю; 3) правопорушник у певних випадках приховує інформацію про своє місце роботи, а слідчий не вживає достатніх заходів для його встановлення.

Як правило особи, які вчиняють погрози або насильство щодо працівників правоохоронних органів зайняті у сфері низькокваліфікованої важкої фізичної роботи. Аналіз вивчених М. Д. Моховим матеріалів це також підтверджує - практично кожна третя особа, яка посягає, відноситься до робітників. У той же час відсоток кримінальної активності службовців виявився найнижчим [15, c. 109]. Прикро, але трапляються 
випадки, вчинення злочину, передбаченого ст. 345 КК України, представниками влади [19].

Висновки. Отримані дані дають змогу розробити кримінологічний портрет особи, яка вчиняє погрози або насильство щодо працівників правоохоронних органів у зв'язку 3 виконанням цим працівником службових обов'язків: чоловік у віці 2550 років, громадянин України, місцевий мешканець міста, 3 загальною середньою або професійнотехнічною освітою, котрий офіційно не працевлаштований, зловживає алкогольними напоями та раніше вчинив адміністративне чи кримінальне правопорушення (у певних випадках раніше судимий).

Інформація про типові риси кримінальних правопорушників цієї категорії дозволяє краще зрозуміти детермінанти цих суспільно небезпечних діянь, механізм їх вчинення та диференціювати заходи запобігання на загально соціальному, спеціально-кримінологічному та індивідуальному рівнях.

\section{Список використаних джерел}

1. Кримінальна відповідальність за злочини, вчинені злочинною спільнотою (статті 255, 2551, 255², 2553, 256 Кримінального кодексу України): науковопрактичний коментар / А. А. Вознюк, О. О. Дудоров, С. С. Чернявський. Київ: Норма права, 2021. 130 с.

2. Вознюк А. А. Теоретичні та практичні проблеми кримінальної відповідальності за створення злочинних об'єднань та участь у них як посягання на громадську безпеку: автореф. дис. ... д-ра юрид. наук: 12.00.08. Київ, 2018. 38 с.

3. Вознюк А., Дудоров О. Кримінальна відповідальність за злочини, вчинені злочинною спільнотою: аналіз законодавчих новел. Новітні кримінально-правові дослідження - 2021: Альманах наукових праць / за ред. проф. Є. Л.Стрельцова, проф. 0. В. Козаченка, PhD 0. М. Мусиченко. Миколаїв: МІП НУ ОЮА, 2021. С. 21-31.

4. Вознюк А. А. Реальні причини топ-корупції в Україні та нереальні способи протидії їй. Реалізація державної антикорупційної політики в міжнародному вимірі: матеріали IV Міжнар. наук.-практ. конф. (Київ, 12 груд. 2019 р.): у 2 ч. / [редкол.: В. В. Чернєй, С. Д. Гусарєв, С. С. Чернявський та ін.]. Київ: Нац. акад. внутр. справ, 2019. Ч. 1. С. $44-47$.

5. Михайленко Д. Г. Протидія корупційним злочинам засобами кримінального права: концептуальні основи: монографія. Одеса : Видавничий дім «Гельветика», 2017. 582 с. $6-9$.

6. Дудоров 0. О., Коломоєць Т. О., Кушнір С. М., Макаренков О. Л. Загальнотеоретичні, адміністративно- та кримінально-правові основи концептуалізації антикорупційної реформи в Україні: колективна монографія. Запоріжжя, 2019. 476 с.

7. Вознюк А. А. Кримінальне право України. Загальна частина: конспект лекцій; вступне слово д.ю.н., проф. О. О. Дудорова. Київ : Нац. акад. внутр. справ, 2016. 236 с.

8. Кримінологія: підручник [Текст] / О. М. Джужа, В. В. Василевич. В. В. Чернєй, С. С. Чернявський та ін.; за заг. ред. д-ра юрид. наук, проф. В. В. Чернєя ; за наук. ред. д-ра юрид. наук, проф. О. М. Джужі. Київ : ФОП Маслаков, 2020.612 с.

9. Кримінологія: підручник / за ред. В. В. Голіни, Б. М. Головкіна. Харків: Право, 2014. 440 c.

10. Кримінологія: підручник / за заг. ред. Ю.В.Нікітіна, С.Ф. Денисова, Є.Л. Стрельцова. Харків: Право, 2018. 416 с. 
11. Вирок Бориспільського міськрайонного суду Київської області від 11.01.2021 р. у справі № 359/10126/20. Єдиний державний реєстр судових рішень. URL: https://reyestr.court.gov.ua/Review/94131310

12. Вирок Святошинського районного суду м. Києва від 03.03.2021 р. у справі № 759/22422/20. Єдиний державний реєстр судових рішень. URL: https://reyestr.court.gov.ua/Review/94531933

13. Вирок Дарницького районного суду м. Києва від 16.02.2021 р. у справі № 753/22295/20. Єдиний державний реєстр судових рішень. URL: https://reyestr.court.gov.ua/Review/94986947

14. Кримінологія: підручник для студентів вищих навч. закладів / за заг. ред. О.М. Джужи. Київ: Юрінком Інтер, 2002. 416 с.

15. Моховой М. Б. Криминологическая характеристика и предупреждение преступлений, посягающих на представителей власти: дисс. ... канд. юрид. наук: 12.00.08. Краснодар, 2004. 230 с.

16. Андрушко А. В. Кримінологічна характеристика осіб, які вчинили незаконне позбавлення волі або викрадення людини. Науковий вісник Міжнародного гуманітарного університету. Серія: Юриспруденція. 2019. Випуск 40. С. 121-128.

17. Вирок Автозаводського районного суду м. Кременчука у справі №524/942/21. Єдиний державний реєстр судових рішень. URL: https://reyestr.court.gov.ua/Review/95264991

18. Вирок Жовтневого районного суду м. Кривого Рогу від 22.01.2021 р. у справі № 212/9342/20. Єдиний державний реєстр судових рішень. URL: https://reyestr.court.gov.ua/Review/94285979

19. Ексзаступник Кличка постане перед судом за бійку 3 поліцейським. 10 червня 2020 p. Українська правда. URL: https://www.pravda.com.ua/ news/2020/06/10/7255141/

\section{References}

Vozniuk, A. A., Dudorov, 0. O., Cherniavskyi, S. S. (2021). Kryminalna vidpovidalnist za zlochyny, vchyneni zlochynnoiu spilnotoiu (statti 255, 255-1, 255-2, 255-3, 256 Kryminalnoho kodeksu Ukrainy): naukovo-praktychnyi komentar. Kyiv: Norma prava [in Ukrainian].

Vozniuk, A. A. (2018). Teoretychni ta praktychni problemy kryminalnoi vidpovidalnosti za stvorennia zlochynnykh obiednan ta uchast u nykh yak posiahannia na hromadsku bezpeku: avtoref. dys. ... d-ra yuryd. nauk: 12.00.08. Kyiv [in Ukrainian].

Vozniuk, A., Dudorov, O. (2021). Kryminalna vidpovidalnist za zlochyny, vchyneni zlochynnoiu spilnotoiu: analiz zakonodavchykh novel. Novitni kryminalno-pravovi doslidzhennia - 2021: Almanakh naukovykh prats. Mykolaiv: MIP NU OIuA [in Ukrainian].

Vozniuk, A. A. (2019). Realni prychyny top-koruptsii v Ukraini ta nerealni sposoby protydii yii. Realizatsiia derzhavnoi antykoruptsiinoi polityky $v$ mizhnarodnomu vymiri: materialy IV Mizhnar. nauk.-prakt. konf. Kyiv: Nats. akad. vnutr. sprav, 1, 44-47 [in Ukrainian].

Mykhailenko, D. H. (2017). Protydiia koruptsiinym zlochynam zasobamy kryminalnoho prava: kontseptualni osnovy: monohrafiia. Odesa: Vydavnychyi dim «Helvetyka» [in Ukrainian].

Dudorov, O.O., Kolomoyecz', T.O., Kushnir, S.M., Makarenkov, O.L. (2019). Zagal'noteoretychni, administratyvno- ta kry'minal'no-pravovi osnovy konceptualizaciyi antykorupcijnoyi reformy $v$ Ukrayini: kolekty`vna monografiya. Zaporizhya [in Ukrainian].

Vozniuk, A. A. (2016). Kryminalne pravo Ukrainy. Zahalna chastyna: konspekt lektsii. Kyiv: Nats. akad. vnutr. sprav [in Ukrainian].

Holina, V. V., Holovkin, V. M. (red.). (2014). Kryminolohiia: pidruchnyk. Kharkiv: Pravo [in Ukrainian]. 
Nikitin, Yu. V., Denysov, S. F., Streltsov, Ye. L. (red.). (2018). Kryminolohiia: pidruchnyk. Kharkiv: Pravo [in Ukrainian].

Dzhuzha, 0. M. (red.). (2002). Kryminolohiia: pidruchnyk dlia studentiv vyshchykh navch. zakladiv. Kyiv: Yurinkom Inter [in Ukrainian].

Mokhovoi, M. B. (2004). Krymynolohycheskaia kharakterystyka y preduprezhdenye prestuplenyi, posiahaiushchykh na predstavytelei vlasty: dyss. ... kand. yuryd. nauk: 12.00.08. Krasnodar [in Russian].

Andrushko, A.V. (2019). Kryminolohichna kharakterystyka osib, yaki vchynyly nezakonne pozbavlennia voli abo vykradennia liudyny. Naukovyi visnyk Mizhnarodnoho humanitarnoho universytetu. Seriia: Yurysprudentsiia, 40, 121-128 [in Ukrainian].

V. Belenok, Researcher of the Scientific Laboratory on Problems Counteracting of Crime of the Educational and Research Institute No. 1 of the National Academy of Internal Affairs

ORCID: 0000-0001-8214-0522

\section{Criminological characteristics of persons who have committed a threat or violence against a law enforcement officer}

The article analyzes the socio-demographic, criminal law and socio-role characteristics of persons who commit threats or violence against a law enforcement officer, as well as against his close relatives in connection with the performance of official duties by this employee.

Based on the analysis of judicial practice, statistical data on criminal offences and convicted persons, the results of research by scientists, the characteristics of criminal offenders of this category are revealed on the grounds of citizenship, nationality, age, sex, educational level, criminal record, complicity, physical condition, employment and place of residence.

It is argued that information on the typical characteristics of criminal offenders in this category allows a better understanding of the determinants of these socially dangerous acts, the mechanism for their commission and the differentiation of preventive measures at the general social, special kryminological and individual levels.

On the basis of the data obtained, a criminological portrait of a person committing threats or violence against law enforcement officials in connection with the performance of official duties by this employee was developed: a man aged 2550 years, a citizen of Ukraine, a local resident of the city, with a general secondary or vocational education, who is not officially employed, abuses alcoholic beverages and has previously committed an administrative or criminal offense (in certain cases previously tried).

Keywords: threat; violence; law enforcement officer; close relatives; identity of criminal; subject of crime. 